\title{
Biophotonics education and research in the FBME CTU, Prague
}

\section{Miroslav Jelínek, Miroslava Vrbová}

Miroslav Jelínek, Miroslava Vrbová, "Biophotonics education and research in the FBME CTU, Prague," Proc. SPIE 9664, Ninth International Topical Meeting on Education and Training in Optics and Photonics, 96640L (24 October 2005); doi: 10.1117/12.2207765

Event: Ninth International Topical Meeting on Education and Training in Optics and Photonics, 2005, Marseille, France 
This paper is freely available as a resource for the optics and photonics education community.

\title{
Ref ETOP081
}

\section{Biophotonics education and research in the FBME CTU, Prague}

Miroslav Jelínek, Miroslava Vrbová

\begin{abstract}
Basic information about Faculty of Biomedical Engineering CTU will be given. This new one faculty is a part of Czech Technical University in Prague since 2005 . The 5 - year study (bachelour and magisterian) is oriented on the education of student in bioengineering. One of the goal of the FBME CTU is the education of students in optics, biophotonics, lasers and in applications of optics in biomedicine and biology. The details of training and research activities will be given.
\end{abstract}

